\title{
Politisk nyorientering og nationale organisationsproblemer umiddelbart efter genforeningen i 1920
}

\section{af Troels Fink}

Grænsestriden 1918-20 satte dybe skel i den sønderjyske befolkning, og dens virkninger kunne spores $\mathrm{i}$ de følgende år. Aabenraafolk stod mod Flensborgfolk; men dertil kom at der blandt Flensborgfolkene indbyrdes opstod problemer både på kryds og på tværs. På tværs: fordi den nye grænse satte skel mellem de tilbageblevne i Sydslesvig og de i Nordslesvig bosatte; på kryds: fordi nogle Flensborg-folk sluttede sig til Det konservative folkeparti, andre til Venstre. Desuden opstod der blandt Flensborg-folkene uenighed om, hvorledes arbejdet for de danske syd for grænsen burde organiseres.

Året 1920 var et valgår som få. Det begyndte $\mathrm{i}$ kongeriget $\mathrm{i}$ april med det valg til folketinget, som var udløst af påskekrisen, da regeringen Zahle faldt. Valget gav fremgang for de konservative, for Venstre og for socialdemokraterne, og et alvorligt nederlag for de radikale, der siden 1913 havde haft regeringsmagten. I sommeren 1920 blev det nødvendigt at holde valg til både landsting og folketing, fordi indlemmelsen i Danmark af "De Sønderjyske Landsdele “ krævede en grundlovsændring; disse valg gav nærmest status quo. Grundlovsændringen blev vedtaget, men derefter skulle den yderlige bekræftes ved en folkeafstemning; det skete i august. Endelig blev der så i september 1920 udskrevet nye valg til folketing og landsting, de første valg som sønderjyderne kunne deltage $i$. Folketingets mandattal var udvidet fra 140 til 149 , landstingets fra 72 til 76.

For de nye vælgere i Sønderjylland var det en ganske uvant situation at skulle deltage $\mathrm{i}$ danske politiske valg med mange partier. Hidtil havde det været så enkelt: dansk eller tysk. Nu blev det mere kompliceret, også fordi forholdet mellem grænsekampens to lejre skabte særlige problemer.

Den ledende politiske skikkelse blandt de danske i Sønderjylland havde i mange år været $H$. P. Hanssen. Som de danskes repræsentant $\mathrm{i}$ den tyske rigsdag havde han i oktober 1918 rejst det sønderjyske spørgsmål og var derefter stærkt optaget af de mange problemer, som den forestående genforening med Danmark ville rejse, derunder også sønderjydernes kommende repræsentation på rigsdagen. Allerede kort efter Tysklands sammen- 


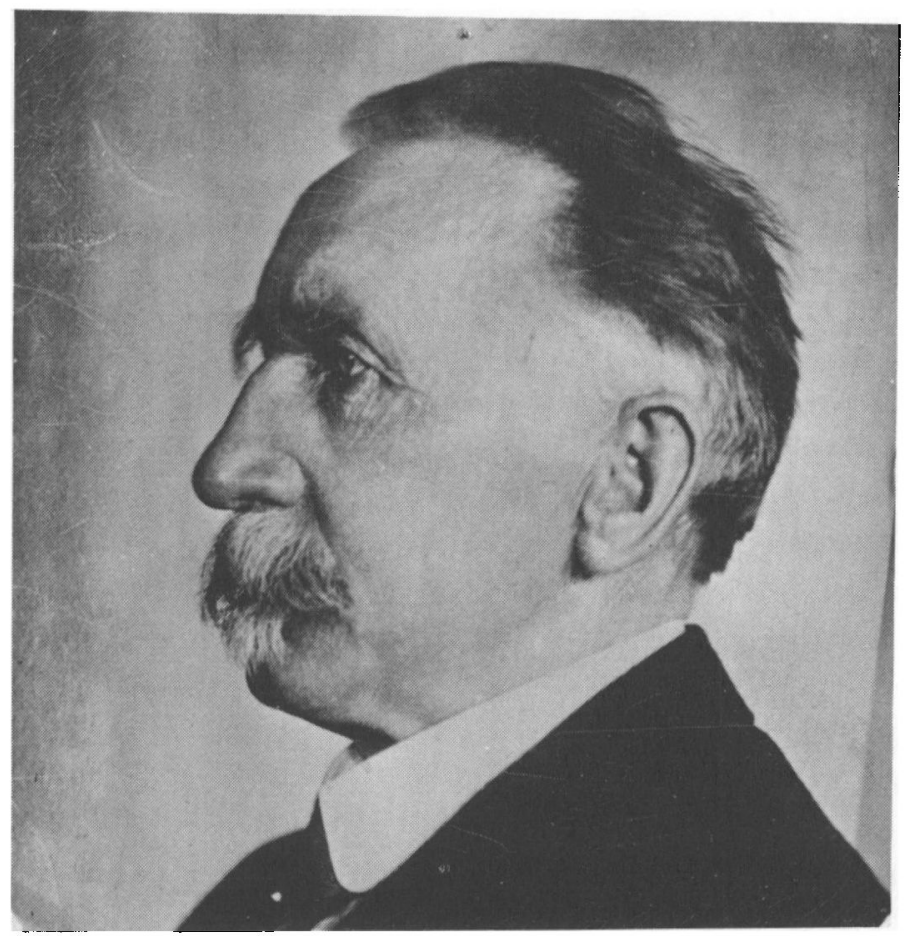

H. P. Hanssen (1862-1936). Foto Elfelt, o. 1920 (Historiske Samlinger).

brud i november 1918 havde han med de nye forhold for øje foreslået, at sønderjyderne $i$ den første valgperiode skulle danne en egen gruppe $i$ folketinget. Gruppen skulle ikke være bundet til noget parti, men blot varetage sønderjyske interesser.

Der var meget som talte for en sådan overgangsordning; der kunne være god grund til at ønske en indlevelsesperiode i indre dansk politik. Men det var fra første færd en urealistisk tanke, dels fordi den forudsatte enighed blandt de ledende sønderjyder, en enighed som ikke fandtes, og dels fordi den forudsatte accept fra de kongerigske partier, en accept som umuligt kunne forventes af alle partier. Allerede ved nytårstid 1919 var mulighederne for at oprette et særligt sønderjysk parti meget små; i forsommeren 1920, da H. P. Hanssen for alvor tog ideen op, var de slet ikke tilstede. Efter grænsestridens oprivende sammenstød, og som partimodsætningerne havde udviklet sig i Danmark, kunne man ikke regne med en rimelig chance for samling på det grundlag, som H. P. Hanssen skitserede. Der kunne kun blive tale om, at Aabenraa-folkene ville gå ind $i$ et sådant parti. 
Når H. P. Hanssen alligevel i maj 1920 indledte forsøget, skyldes det nok, at han på det tidspunkt var uden politisk basis. Den nordslesvigske Vælgerforening var $i$ en opløsningstilstand, og der var ikke plads for ham $i$ regeringen Neergaard. Regeringen Neergaard havde støttet en internationalisering af Flensborg; H. P. Hanssen havde taget afstand derfra, det hindrede ham i at slutte sig til partiet Venstre, der ellers lå ham nærmest. Forsøget på at oprette et særligt Sønderjydsk Venstre slog fejl; i Sønderjyske Årbøger 1977 har cand. mag. Agnes Schmidt Poulsen skrevet en udmærket artikel derom: "Etableringen af partiet Venstre i Nordslesvig efter genforeningen". Den skal der her henvises til, her er det formålet så se lidt på, hvad der videre fulgte.

Lige så lidt som H. P. Hanssen kunne slutte sig til Venstre, var han i stand til at følge Det radikale venstre. Nok havde han været enig med de radikale i grænsespørgsmålet, men han var imod partiets almene program, specielt $\mathrm{i}$ forsvarsspørgsmålet, og han nærede ikke særlig venlige følelser over for den afgåede statsminister $\mathrm{C}$. Th. Zahle.

Det var en stor skuffelse for H. P. Hanssen, at forsøget med et sønderjysk Venstre mislykkedes, men det skal man næppe beklage, ej heller set fra H. P. Hanssens side. Sandsynligvis var der blevet stemmer nok til både ham og Nis Nissen, men som løsgængere havde de fået trange kår, idet de måtte regne med modstand både fra Venstre og fra de konservative, der tilsammen udgjorde det parlamentariske grundlag for regeringen Neergaard.

Dog må man opfatte sammenbruddet af forhandlingerne om Det sønderjyske venstre $i$ august 1920 som et alvorligt nederlag for H. P. Hanssen. Han stod nu helt uden for det organiserede politiske liv, men valget til folketinget den 21. sept. blev til gengæld en overvældende og uventet succes for hans syn på sønderjysk politik - og på en måde en oprejsning for ham. Det viste sig også, at hans modstandere, Flensborg-folkene, nu stod over for store vanskeligheder. Under grænsestriden 1918-20 havde retningen omfattet tilhængere både $\mathrm{i}$ første og anden zone; efter grænsedragningen var opgaverne væsensforskellige i de to zoner. For de danske $i$ anden zone gjaldt det at indrette sig under de givne vilkår og at bygge et nyt organisationsapparat op. I første zone derimod gjaldt det at finde den rette partibås, for der var to muligheder. Både de konservative og Venstre bejlede til Flensborgfolkene. I venstre indledtes et samarbejde mellem et Flensborg-venstre og et Aabenraa-venstre, som foregik under store vanskeligheder, uanset at de to parter kunne enes om at fordele kredsene mellem sig, 4 til Aabenraa-venstre og 3 til Flensborg-venstre, det svarede nogenlunde til styrkeforholdet. Men aftalen kom så pludseligt, at det nok kunne forvirre både den ene og den anden.

For meningsdannelsen i Nordslesvig havde de forskellige dagblade spillet 
en afgørende rolle. Derfor fik det stor betydning, at det førende blad i Haderslev, Modersmålet-Dannevirke, på en generalforsamling den 1. juli 1920 besluttede for fremtiden at være et venstreblad. Det samme gjorde Dybbøl-Posten under Andreas Grau og Tycho Filskov. I grænsestriden havde Modersmålet støttet H. P. Hanssen, mens Dybbøl-Posten havde holdt på Flensborg-standpunktet. H. P. Hanssens blad Hejmdal holdt sig foreløbig uden for partierne, men støttede i realiteten Aabenraa-venstre.

I Haderslev havde redaktør A. Svensson i 1919 oprettet dagbladet Danskeren, som i sommeren 1920 sluttede sig til Det konservative folkeparti, men det opnåede kun en relativt beskeden udbredelse. Flensborg Avis havde de fleste af sine abonnenter nord for den nye grænse og stillede sig sympatisk til både de konservative og Venstre som de to "nationale " partier. Men avisen kom til at sidde mellem to stole, for hverken det ene eller det andet parti var tilfredse, når Flensborg Avis ikke gav fuldtonende støtte.

De ledende Flensborg-folk havde delt sig mellem de to partier. Peter Grau, Pøl, gik med de konservative ligesom bankdirektør R. P. Rossen, Tønder, og gårdejer Hans Lorenzen, Ballum. Til Venstre sluttede sig Andreas Grau, H. D. Kloppenborg-Skrumsager og N. J. Gotthardsen. Dyrlæge C. O. Pedersen,

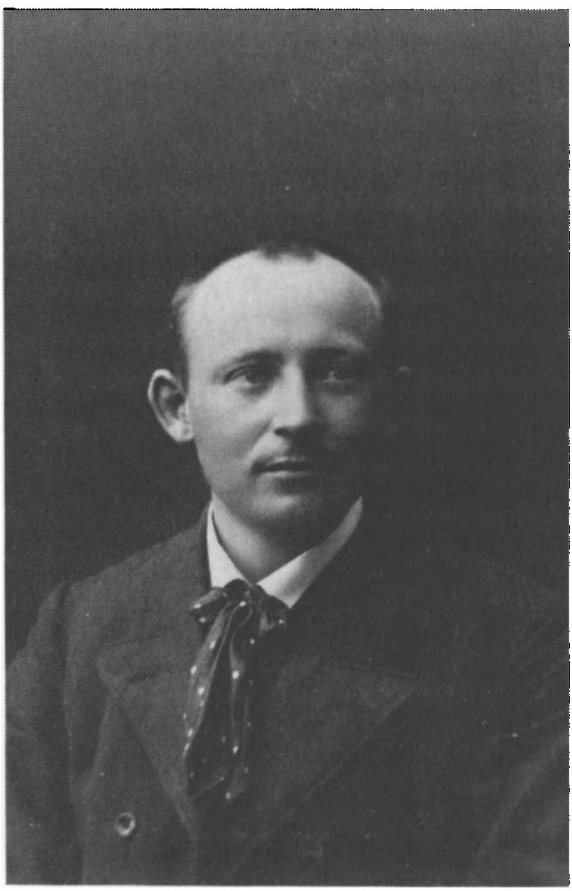

Adolf B. Svensson (1880-1963). Foto A. Jergensen, Senderborg, 1907 (Historiske Samlinger). 
Jels, var også en ivrig talsmand for Flensborg-venstre. Andreas Grau var den blandt Flensborg-venstremændene, der var ivrigst for at nå til forståelse med Aabenraa-venstre. Han havde god kontakt med statsminister Neergaard, og straks, da genforeningsfestlighederne var forbi, var han begyndt arbejdet med at oprette venstreforeninger. Da planerne om Det sønderjyske venstre var strandet 10. august 1920 begyndte også Aabenraa-folkene at danne venstreforeninger.

Den 21. august traf repræsentanter for de to Venstre-grupper hinanden. For Aabenraa-retningen mødte bl.a. gårdejerne Martin Simonsen, Flovt, Chr. E. Christensen, Asserballe, Mads Gram, Københoved, Chr. Iversen, Sønderballe, P. J. Refshauge, Erlev, Martin Wiuff, Sillerup og Falle Lildholdt, Løjt, samt smedemester Wilckens, Bovlund og væver Th. Kaufmann, Bovrup. For Flensborg-retningen bl.a. Andreas Grau, Jørgen Zachariassen, Dybbøl, N. J. Gotthardsen, Nørmark, Jørgen Gram, Gabøl, H. D. Kloppenborg-Skrumsager, Københoved, Søren Ratzer, Rangstrup. (Dybbøl-Posten 24. august 1920).

Dybbøl-Posten skrev den 25. august: "Det gælder nu ikke om at glemme fortiden, men om at se fremad. Det gælder ikke om at hugge en hæl og klippe en tå, men om af ærlig overbevisning som ligemænd at mødes der, hvor fremtidens opgaver ligger. Der kræves ingen overbevisningsofre af nogen, men god dansk vilje af alle“. De to delegationer enedes om at dele de 7 opstillingskredse: Aabenraa-retningen fik Rødding-, Haderslev-, Aabenraaog Augustgenborgkredsene, Flensborg-retningen Sønderborg-, Tønder- og Løgumklosterkredsene.

Men da man kom til personspørgsmålene, slog modsætningerne gnister. Det harmede Flensborg-folkene, at Chr. Ernst Christensen blev opstillet $\mathrm{i}$ Augustenborg-kredsen. Han var udpræget Aabenraa-mand, og han var en hård konkurrent til den udprægede Flensborg-mand Andreas Grau, der blev opstillet i Sønderborg-kredsen. Chr. Ernst Christensen indledte forøvrigt sin valgkamp med en meget forsonlig tale, som dog ikke tilfredsstillede bladet Danskeren. Det gav venstrebladet Sorø Amtstidende anledning til at udtale sin forundring over, at Danskeren ikke kunne bifalde "Chr. Ernst Christensen forsonlige og fornuftige ord«. Men Danskeren svarede den 21. august 1920: "At grænsestriden ikke mere har praktisk betydning er for så vidt rigtigt, som den afgørelse, der nu er truffet, næppe lader sig ændre i alt fald $i$ en overskuelig fremtid. Men vi tillægger det den allerstørste betydning, at det danske folk ikke opgiver håbet om en fremtid for danskheden i Mellemslesvig og heller ikke uden videre slår sig til ro med måden, hvorpå denne afgørelse blev hidført. Og vi undrer os højligen over, at man fra en side, hvor der er holdt liv i de gamle provisoriestridigheder gennem en menneskealder, vil 
kræve af os, der af hele vor sjæl har deltaget $i$ kampen for danskhedens ret $i$ Mellemslesvig, at vi skal glemme på mindre end et år. Vi vil tværtimod mene, at de modsætninger, der trådte frem i grænsestriden, vil møde os også herefter på andre områder, som de i virkeligheden har mødt os før i tiden, da kampen om edsaflæggelsen rasede hernede. Thi de beror på et vidt forskelligt grundsyn, på et skel man ikke skræver henover, hverken ved hjælp af lyriske talemåder eller politisk organisationsarbejde."

Endnu mere forargede blev Flensborg-folkene, da redaktør Anders Lebeck blev opstillet i Aabenraa-kredsen. Han var $\mathrm{H}$. P. Hanssens håndgangne mand og havde taget mangen en polemik med Flensborg-retningen. Til gengæld livede hans opstilling meget op på bladet Hejmdal, der nu gik ind i valgkampen med fuld musik til fordel for Aabenraa-kandidaterne.

Der var mindre blast om P. J. Refshauge i Haderslev-kredsen og Mads Gram i Rødding-kredsen. På vestkysten var der derimod interne vanskeligheder for Flensborg-retningen. Her ønskede nogle af de ledende med støtte fra Flensborg Avis at få opstillet den tidligere landdagsmand KloppenborgSkrumsager, men han var tilsyneladende mindre folkeyndet, end man havde regnet med. I Løgumkloster-kredsen blev han vraget til fordel for N. J.

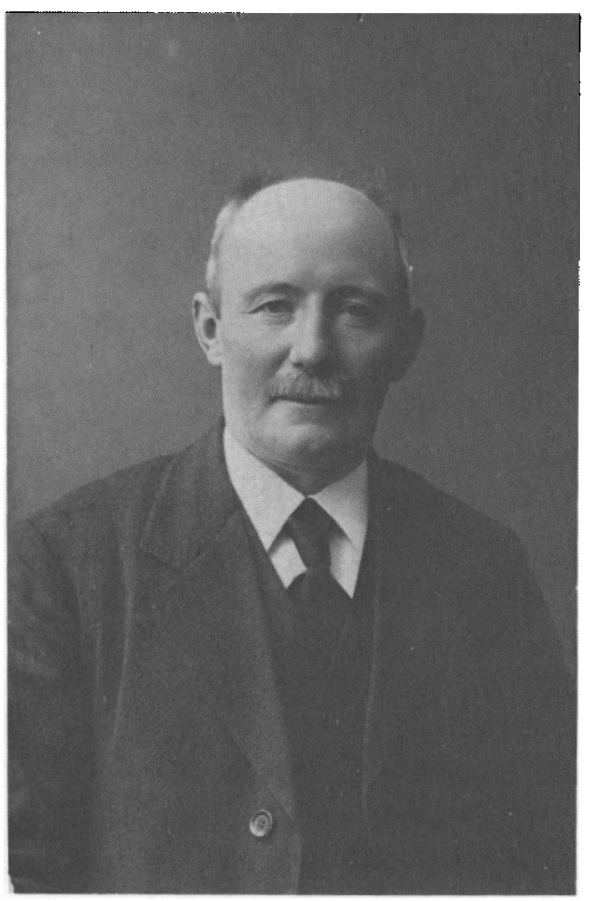

Hans Jefsen Christensen, Hegsbro (18801956). Tingvalgt landstingsmand for Venstre 1920-1947, foto Norgaard Nielsen. Ribe (Historiske Samlinger). 
Gotthardsen, og i Tønder-kredsen blev han fortrængt af den Sønderjyske Skoleforenings formand, Hans Jefsen Christensen, som stod imellem retningerne. Danskeren skrev i sin kommentar: ${ }^{4}$ Flensborg Avis har ikke engang været $i$ stand til at få Kloppenborg opstillet. I stedet for kan bladet få lov at støtte den halvt Flensborg-venlige, halvt Aabenraa-venlige og halvradikale H. Jefsen Christensen fra Høgsbro «. (Danskeren 7. sept. 1920) Den sidste "halvdel «, den radikale, skyldtes, at Jefsen Christensen havde talt ved et kristeligt møde i Horsens, hvor også højskoleforstander Holger Begtrup havde været taler. (Danskeren 3. juli 1920) Begtrup var optrådt som modstander af Flensborg-bevægelsen og var derfor ugleset $\mathrm{i}$ konservative blade.

De andre partier havde ikke samme problemer som Venstre. Som en selvfølge var Det konservative folkepartis kandidater Flensborg-tilhængere. Sønderjysk arbejderforening, der indgik valgsamarbejde med Det radikale venstre, delte Aabenraa-retningens opfattelse af grænsepolitikken. Det samme gjorde socialdemokratiet. Det tyske mindretal organiserede sig i Schleswigscher Wählerverein og deltog som sådan i valget den 21 . september. Valgresultatet fremgår af følgende oversigt:

$\begin{array}{lcc} & \text { stemmer } & \text { mandater } \\ \text { Venstre } & 24.222 & 4 \\ \text { Konservative } & 7.177 & 1 \\ \text { Radikale } & 4.435 & 1 \\ \text { Socialdemokrater } & 6.432 & 1 \\ \text { Tyskerne } & 7.438 & 1\end{array}$

Desuden opstillede Erhvervspartiet og Venstresocialisterne, der fik henholdsvis 1.234 og 505 stemmer.

Det spændende moment ved valget var fordelingen af Venstremandaterne på Flensborg- og Aabenraa-mænd. Det viste sig, at alle de fire Venstremandater var tilfaldet Aabenraa-retningens kandidater. Valgt blev P. J. Refshauge (Haderslev), Chr. Ernst Christensen (Augustenborg), M. K. Gram (Rødding) og Anders Lebeck (Aabenraa). Holger Andersen fik det konservative mandat, J. P. Nielsen det socialdemokratiske og pastor Schmidt det tyske. Chr. Lageri fik et radikalt tillægsmandat.

Resultatet var en dyb skuffelse for de konservative; og for Flensborgretningen som sådan var valget ganske utilfredsstillende; det svarede ikke til styrkeforholdet mellem de to retninger.

Som nævnt havde Flensborg Avis ydet støtte både til Venstre og til Det konservative folkeparti. Men situationen var vanskelig for bladet både under valgkampen og ikke mindst efter. De konservative var fortørnede over ikke 


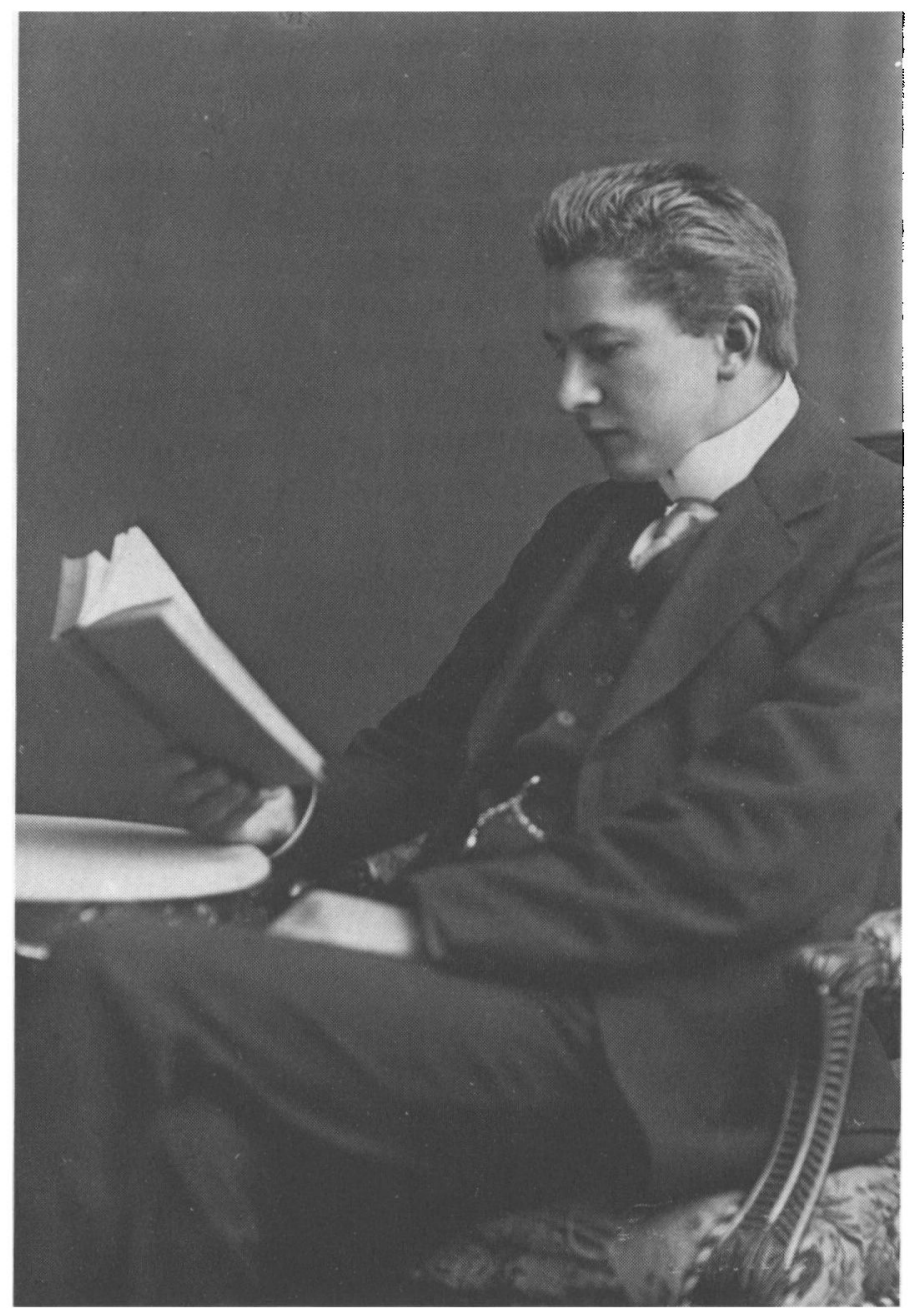

Holger Andersen (1890-1961). Konservativ politiker, valgt som folketingsmand i den senderjyske storkreds 1920-1930, landstingsmand 1936-1939, foto o. 1920 (Historiske Samlinger).

at få ubetinget støtte fra Flensborg Avis, og de henviste til, at de under grænsestriden havde givet fuld opbakning til bladet og dets politik. De konservative fandt, at Venstre havde fået for megen assistance. Den 30. august 1920 skrev Danskeren: "Men det er naturligvis forståeligt, ja endog sandsynligt, at Det konservative folkeparti ikke har forudset, at denne virksomme støtte af mellemslesvigske krav og ønsker til syvende og sidst skulle resultere i en særlig flensborgsk forkærlighed for Venstre. Og det vil 


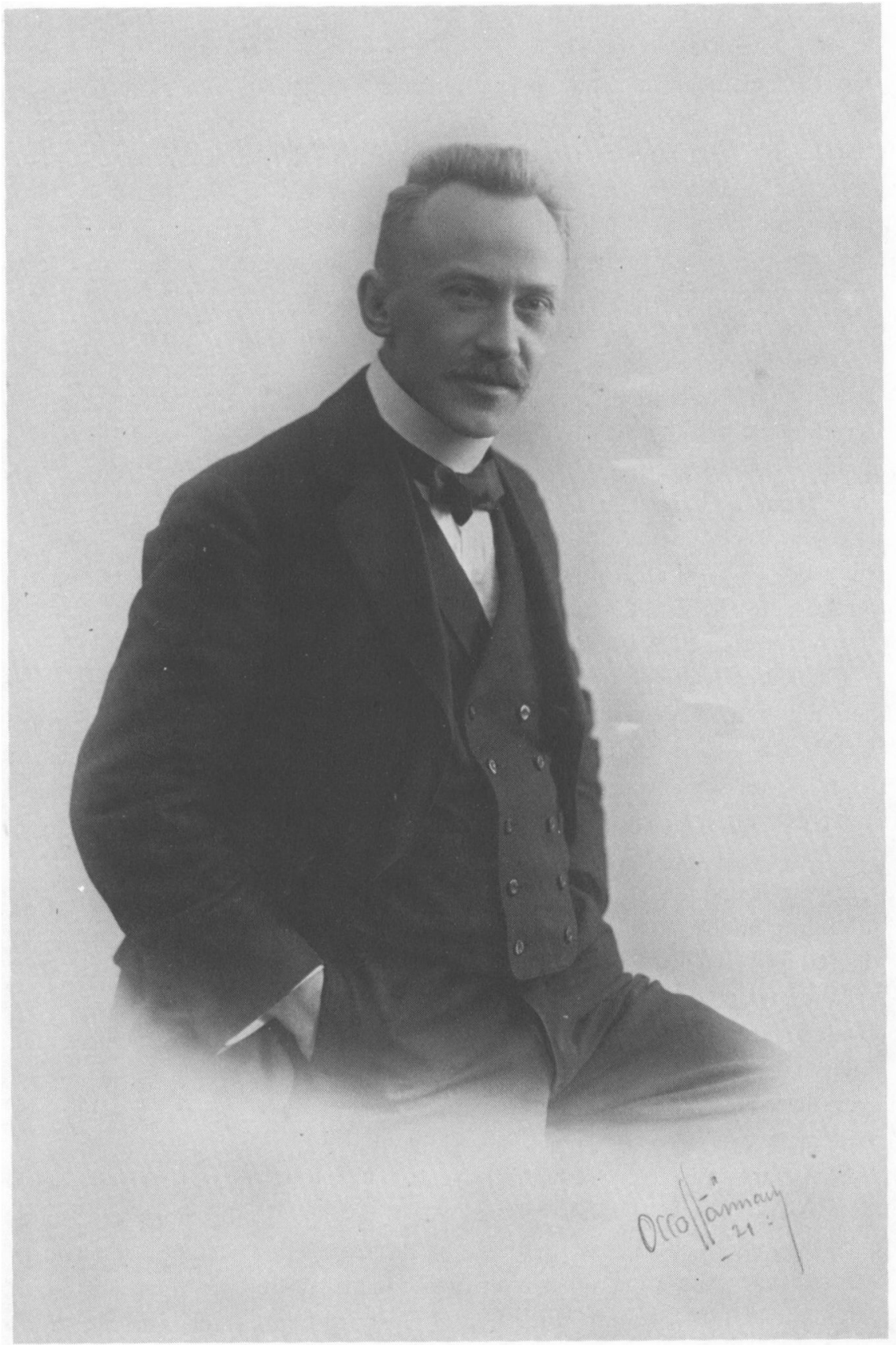

Ernst Christiansen (1877-1941). Redaktor af Flensborg Avis 1906-1940. Foto Otto Hannach, 1921 (Historiske Samlinger). 
være en overraskelse for mange, at Flensborg Avis, tilsyneladende fuldstændig overser den nationale opgave, der ligger $i$ at styrke det af de danske partier, der indtil dato har udvist det mest vidtgående kendskab til og den største forståelse for mellemslesvigske forhold. Vi skal ikke gøre forsøg på at overbevise Flensborg Avis om kortsynetheden i den konjunkturpolitik, det fører for øjeblikket. Det vil hurtigt vise sig, at bladet som hidindtil således også i fremtiden vil blive nødt til fortrinsvis at søge vidtgående hjælp og støtte for sine anskuelser både hos de konservative kredse i det danske folk og hos disse kredses politiske reprasentation på rigsdagen «.

I det konservative blad Nordjylland indledtes en artikel med den sarkastiske bemærkning: "Flensborg Avis har sikkert glemt, hvad smedens kat døde af " (citeret i Danskeren 7. september 1920). Ribe Stiftstidende og Kolding Avis sluttede op i rækken. Da valget var endt med fiasko for Flensborg-retningen, blev tonen endnu skarpere. Erik Hansen $i$ Kolding Avis anså redaktør Ernst Christiansens standpunkt for en fejl og for en troløshed, "der ikke kunne andet end såre. Man har ikke ventet eller ønsket, at Flensborg Avis skulle optræde som konservativt organ, men man har på den anden side heller ikke kunnet vente en ligefrem fjendtlig eller dog noget reserveret optræden fra Flensborg Avis' side overfor folkepartiet".

Flensborg Avis forsøgte at forsvare sig bedst muligt. Den 21. september hed det bl.a.: "At maskepiet mellem Flensborg- og Aabenraa-gruppen i Venstre er uheldig, utiltalende, skikket til at skabe lede ved hele stillingen, er rigtigt. Spørgsmålet er, om alle Flensborg-mænd af den grund skulle have ladet det store Venstreparti ligge og være gået til de konservative, overladende Venstre til H. P. Hanssen og Lebeck. De konservative ville så have fảet nogle tusinde stemmer flere, men Danmarks politiske og nationale udvikling havde måske til gengæld taget så meget mere skade«. Sådan skrev bladet på selve valgdagen. Da resultatet blev kendt, var skuffelsen stor: "Blandt vore landsmænd syd for grænsen vil man have anledning til liden glæde over valgets udfald. De herrer pastor Schmidt, socialdemokraten Nielsen fra København, Lebeck, Mads Gram og Chr. Ernst Christensen samt eventuelt Refshauge, kan sikkert ikke siges at have næret forståelse for mellemslesvigske forhold". (Fl. Av. 23.9.20).

Flensborg-retningen var virkelig kommet til kort, men det kunne der teoretisk i al fald - bødes på ved det forestående landstingsvalg. Valgmændene inden for Venste delte sig på de to retninger, men i Sønderborgkredsen var Aabenraa-venstre utilfreds med, at der på venstrelisten til valgmandsvalget blev opstillet flere Flensborg-kandidater, end de fandt rimeligt. Det fik til følge, at der i denne kreds blev opstillet en særlig valgmandsliste uden for partierne, men det var klart, at Aabenraa-venstre 
stod bag opstillingen. Listen fik valgt 3 valgmænd, deriblandt amtsassessor, dr. Karberg, Sønderborg.

Da selve landstingsvalget fandt sted i Herning, regnedes disse 3 til Venstre, med det resultat, at 49 valgmænd af Aabenraa-venstre stod overfor 42 af Flensborg-venstre. Med lidt hjælp fra det øvrige Jylland betød det et landstingsmandat til hver af grupperne. Flensborg-venstre samlede sig om $\mathrm{H}$. D. Kloppenborg-Skrumsager, Aabenraa-retningen valgte dr. Karberg. Valgmændene fra de to Venstregrupper holdt møde hver for sig. En af valgmændene for Flensborg-venstre, pastor Andersen, Holbøl, skrev i Flensborg Avis (15.10.1920): "Da Flensborg-venstre holdt møde i Herning var der 42 valgmænd tilstede, og mange regnede med, at endnu 2 skulle slutte sig til dem. Indtil $\mathrm{H}$. Jefsen Christensen kom til stede var der fuld enighed indenfor gruppen; han prøvede at forhindre Kloppenborgs valg, men måtte tilsidst give efter; ellers havde splittelsen inden for Venstre nok været fuldbyrdet. Men alle var enige om, at havde de ikke været så mange, havde man ikke taget hensyn til dem.«

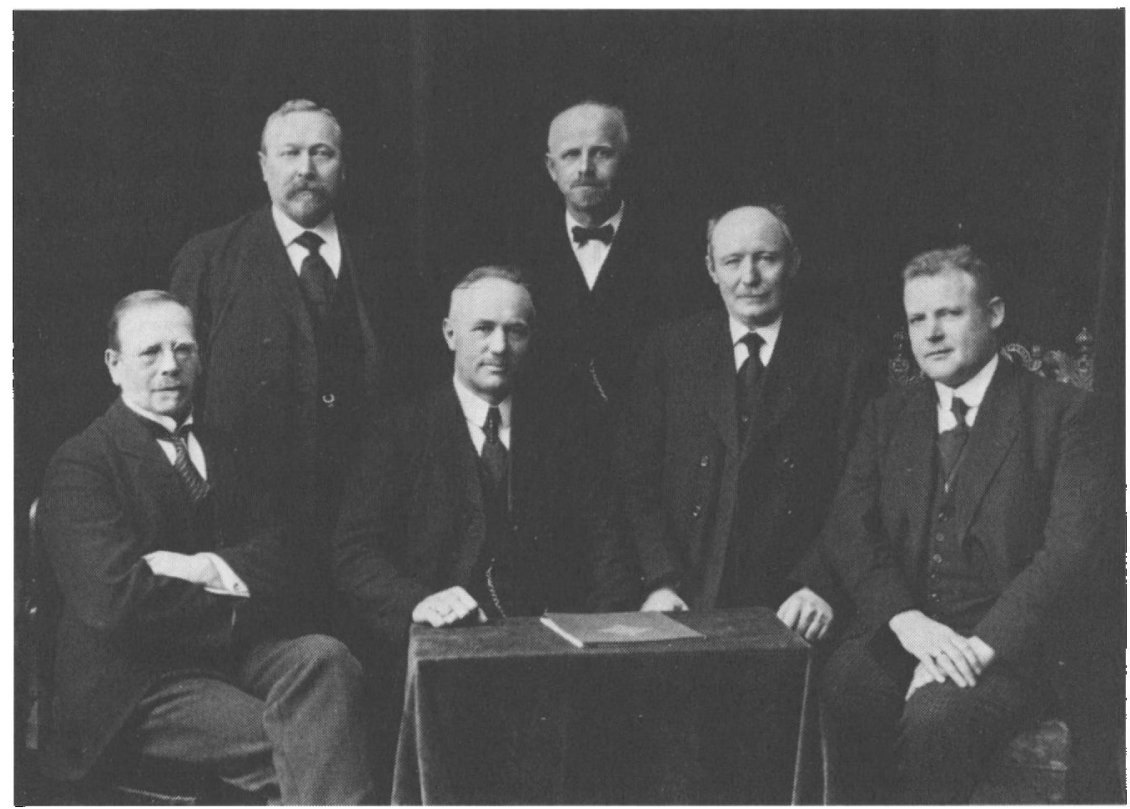

Den talstarke Venstregruppe fotograferet i Aabenraa efter valget 1920. Fra venstre side ses A. Lebeck, Chr. Ernst Christensen, P. J. Refshauge, Mads Gram og landstingsmandene Hans Jefsen Christensen og dr. Karberg. Landstingsmand Kloppenborg-Skrumsager er ikke med pd billedet! (Historiske Samlinger). 
Valget af dr. Karberg som Aabenraa-venstres repræsentant irriterede Flensborg-mændene. Dybbøl-Postens kommentar lød: "I politisk henseende er det ganske uforståeligt, hvorledes netop dr. Karberg kunne vælges til Venstres repræsentant. Han har aldrig lagt skjul på, at han følte sig knyttet til det radikale parti og dets presse, og som valgmand var han opstillet på en splittelsesliste, der var opstillet netop for at tage stemmer fra Venstrelisten «.

Ved en aftale mellem Socialdemokratiet og det tyske mindretal afgav de 24 hjemmetyske valgmænd deres stemmer p\& den dansksindede socialdemokrat Jørgen Møller fra Haderslev, der blev valgt. Dermed var de 3 nye pladser besat.

Men nu skulle disse 3 sønderjyske landstingsmænd, Kloppenborg-Skrumsager, Karberg og Jørgen Møller, tilsammen vælge et tingvalgt landstingsmedlem. Det vil sige, at hvis de to Venstremænd blev enige, kunne de bestemme, hvem den fjerde skulle være. Men de kunne ikke blive enige. KloppenborgSkrumsager holdt på N. J. Gotthardsen, medens Karberg foreslog Hans Jefsen Christensen som en egnet mellemproportional. Til sidst måtte afgørelsen overlades til bestyrelsen for Venstre-gruppen i landstinget. Den foretrak Jefsen Christensen, der hverken holdt med Aabenraa-retningen eller med Flensborg-retningen, men for Aabenraa-folkene var han mere acceptabel end den renlivede Flensborg-mand (eller rettere Dannevirkemand) N. J. Gotthardsen; de to var iøvrigt svogre.

Gør man hele resultatet op, var af de sammenlagt 12 nye rigsdagsmedlemmer: 1 konservativ, 2 socialdemokrater, 7 venstre, 1 radikal og 1 hjemmetysker. Fordeler man dem efter skillelinjen Aabenraa kontra Flensborg havde Aabenraa-retningen fået overtaget med 8 ( 5 venstre, 1 radikal og 2 socialdemokrater) mod 2 renlivede Flensborgmænd og manden i midten, Hans Jefsen Christensen, samt pastor Schmidt fra det tyske mindretal.

Det er forståeligt, at der inden for Flensborg-retningen var megen bitterhed over det nedslående resultat. Som tidligere antydet kom bitterheden til udtryk i hårde konservative angreb på Flensborg Avis, men i denne debat indgik yderligere to forhold, hvor det viste sig, at Flensborg-folkene indbyrdes havde forskelligt syn.

Det ene var oprettelsen af et konservativt blad i Tønder, hvad der muligvis ville påføre Flensborg Avis konkurrence i det område nord for grænsen, hvor avisen stod stærkest. Det andet var planen om at oprette en samlende grænseforening i Danmark til støtte for de danske syd for grænsen.

Der var i Danmark siden 1880'erne blevet oprettet en lang række sønderjyske foreninger, og de havde i fællesskab dannet en centralforening. Under grænsestriden havde disse foreninger spillet en underordnet rolle; der havde været uenighed blandt de ledende personligheder, men nu da 

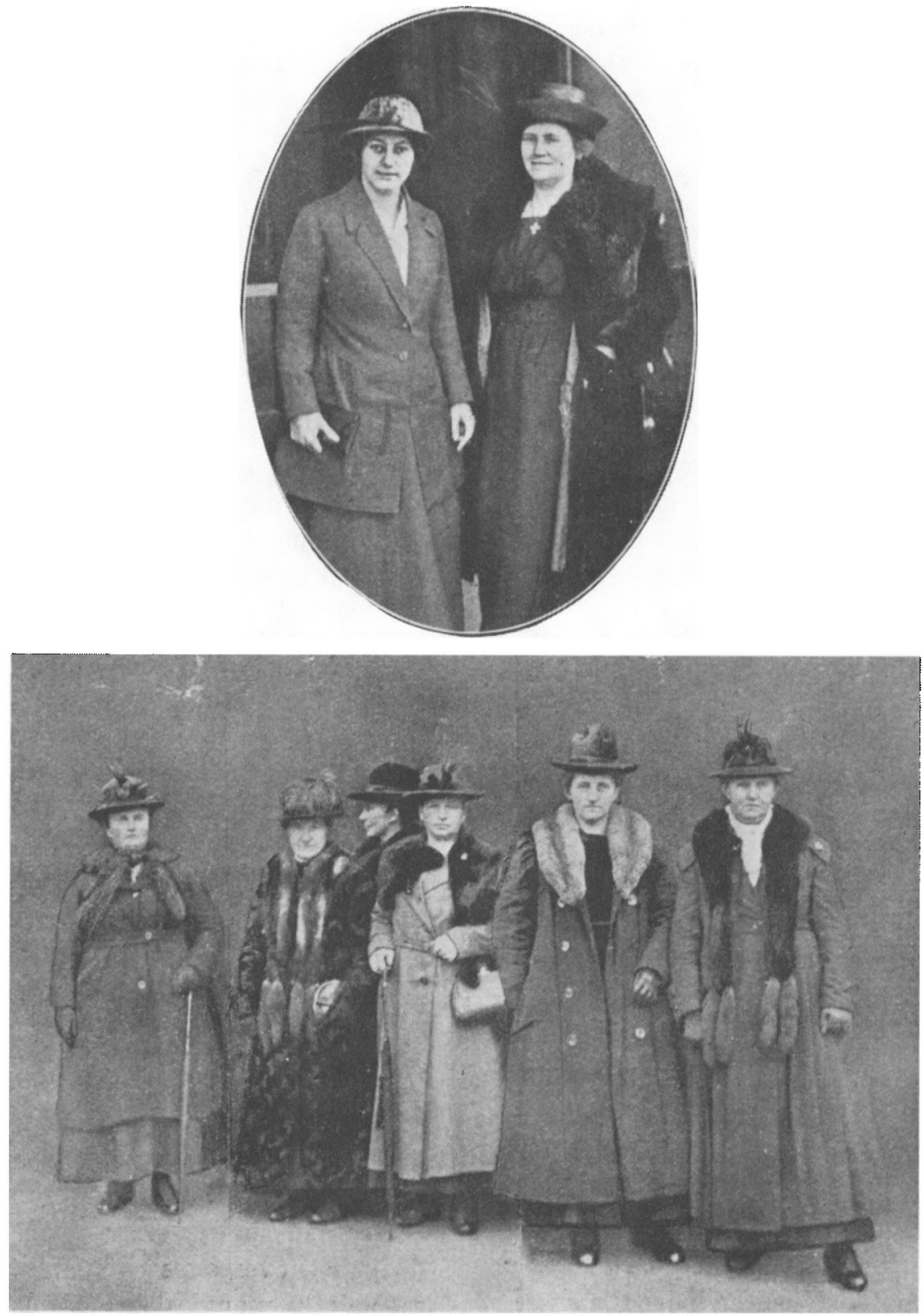

Billederne af de sonderjyske rigsdagsmands hustruer er fra Tidens Kvinder, 9. oktober 1920, der findes $i$ Chr. Lageris arkiv $i$ Landsarkivet. Pa forsiden prasenteres ialt 11 kvindelige rigsdagsmedlemmer. Fra Senderjy/land mätte man indskranke sig til rigsdagsmedlemmernes hustruer, der deltog $i$ hejtidelighederne ved rigsdagens abning. I ovalen finder man fruerne Karberg og Kloppenborg-Skrumsager, på det store billede fruerne Moller, Christensen, Lebeck, Lageri, Gram og Refshauge. Fru pastor Schmidt oplyses i billedteksten at have sendt afbud, mens Holger Andersen var ugift. 
genforeningen var fuldbyrdet, var det naturligt for de fleste af dem at lægge deres arbejdsindsats syd for den nye grænse, og med denne opgave for øje var det naturligt, at det blev Flensborg-folkene, der tog ledelsen. Ernst Christiansen havde tidligt fremsat forslag til samling af kræfterne $i$ en stor organisation, og i sensommeren 1920 var arbejdet begyndt. Samtidig rejstes problemet i Nordslesvig om en organisation, der kunne kanalisere støtten herfra til Sydslesvig. Mens Flensborg Avis med lidenskab gik ind for en stor "Grænseforening “, fandt bladet Danskeren, at flere samvirkende foreninger var at foretrække, efter princippet: marchere adskilt og slå samlet, et princip som H. P. Hanssen forøvrigt havde hyldet i Nordslesvig før krigen og stadig fandt rigtigt.

Det kom til en række skarpe meningsudvekslinger, som yderligere fik næring, da den nye konservative Tønder Amts Avis, redigeret af Ingvald Kieler, udover den døgnaktuelle debat bragte en artikel, der indeholdt en mandjæuning mellem Ernst Christiansen og Adolph Svensson. Den afslørede, at der bestod et dybtgående modsætningsforhold mellem disse to. Artiklen citeres her efter Kolding Avis 5. oktober 1920; den blev bragt under overskriften: "Manden, der forblev tro “, og den var i Kolding Avis forsynet med en "manchet " hvori det hed: "I Tønder Amts Avis påtaler redaktør Ingvald Kieler, at Flensborg Avis vender sig mod den konservative presse. Redaktør Kieler påtaler særlig den måde, hvorpå Flensborg Avis flere gange har stiklet til redaktør Svenssons arbejde for mellemslesvigerne. Kieler betegner Flensborg Avis' fremgangsmåde som ganske utilbørlig og skriver: "Det ville være urigtigt for dem, der kender sagens rette sammenhæng, at tie stille hertil. Ikke fordi redaktør Svensson ikke kan svare for sig selv og alt har gjort det med vanlig applomb, men fordi en bladmand i visse tilfælde overfor visse arter af angreb nok kan gøre fordring på, at andre griber til værge for ham. Redaktør Svenssons første forhold til mellemslesvigerne er det, at han ligesom Flensborg Avis' nuværende redaktør - kom fra det nordslesvigske bondeland ind til Flensborg Avis' kontor og blev elev af Jessen. Man kan vist roligt sige hans mest yndede elev, - $\mathrm{i}$ hvert fald den, der stod ham personlig nærmest, så længe han var ved bladet. Og der er vel dem, der mener, at han også bedst kunne have fyldt Jessens plads ved hans bortgang, idet det udprægede journalistiske talent hos den, der blev Jessens efterfølger, ikke helt kan opveje savnet af det politiske klarsyn og fremblik og den velgørende, usmålige grejhed, der præger redaktør Svenssons person. Skæbnen ville, at Svensson kom væk fra Flensborg Avis til Dybbøl-Posten, og Christiansen blev. Dette bevirkede vel ofte et forskelligt syn og deraf følgende sammenstød, men hovedlinjen for Jessens politik trådte oftest klarest frem i DybbølPosten. Måske ikke klogest og varsomst (det gav både rifter og sår så 
ubøjeligt at følge Jessens linje for en ny mand ved et nyt blad) men sikrest og modigst. Her var $i$ hvert fald ingen skæven efter at bevare en stor og $i$ visse udkanter lidt usikker abonnentkreds eller fornem tenderen hen mod at blive et orakelmæssigt centrumsblad. Her var en hensynsløs og velgørende stillen sagen over bladpolitik. Svensson kunne nu, da hans bladlige livsarbejde var blevet knyttet til det egentlige Nordslesvig, let være blevet fristet til at stille Mellemslesvigs sag i anden række. Det skal siges til hans ære, at han aldrig gjorde det. Vel drev hans bladskabne ham langere op i Nordslesvig, fra Sønderborg til Haderslev, fra Dybbøl-Posten til Danskeren, men altid var hans første interesse og varmeste ildhu at følge med $\mathrm{i}$ arbjdet for mellemslesvigerne.

Hvem, der har gjort mest nytte i dette arbejde, er det urimeligt at diskutere. I Flensborg selv ville man åbenbart nødig give ham lokalt virkefelt. Vel, så blev han tvunget mod nord og tvungen til at gøre arbejdet for mellemslesvigerne nord på. Og her har han da også med trofasthed gjort mellemslesvigernes sag så megen nytte som andre sydpå. I Haderslev amt ville Flensborgbevægelsen uden Danskeren have haft omtrent lige så vanskelige vilkår som i Aabenraa amt. Og videre nordpå i kongeriget var Svensson frem for nogen banebryder for de flensborgvenlige synspunkter. Det skyldes således særlig ham, at Det konservative folkeparti så tidlig og så afgjort blev orienteret $i$ flensborgvenlig retning. På store offentlige møder såvel som på mere personlige påvirkningsrejser blev han brugt til overflod, og han lod sig villigt bruge uden småligt hensyn til, hvad hans nystartede blad kunne kræve af personlig nærværelse"."

Kolding Avis føjede til: "Hvad Kieler her har skrevet om redaktør Svenssons personlighed og arbejde kan vi fuldtud tiltræde. Hans arbejde ved Danskeren, og under hele Flensborg-kampagnen for Flensborgs og Mellemslesvigs ret har vi haft lejlighed til at følge på nært hold, og vi har set, at det var båret af uegennyttig ildhu, og at akkordens ånd var det fremmed. Han er forbleven tro mod Jessens idealer, og han ejer den mandige fasthed i sindet, der hører til det at vedstå og praktisere dem i en tid, da sønderjysk politik til ubodelig skade for grænsespørgsmålet forsumpede (og forsumpes) $\mathrm{i}$ taktiske hensyn og klogskab; det vil sige: bliver et uendelig småtskåret spil om, hvem der har været den snedigste."

Sagt med andre ord beskyldte Erik Hansen i denne tilføjelse Ernst Christiansen for at have svigtet Jessens idealer, mens Ingvald Kieler havde ladet forstå, at Ernst Christiansens journalistiske talent ikke opvejede hans mangel på politisk klarsyn og fremblik, og at Flensborg Avis tenderede til at blive et orakelmæssigt centrumsblad. Det blev også sagt, at A. Svensson var den af Jessens elever, der stod læremesteren nærmest, og at Svensson havde 
følt, at der i 1919 ikke var brug for ham i Flensborg, underforstået på Flensborg Avis, men artiklen siger ikke noget om det politiske modsætningsforhold, der bestod mellem Ernst Christiansen og fru Marie Jessen på den ene side (de var tilhængere af Danevirke-grænsen) og på den anden side A. Svensson, der var en af de ledende i Flensborg-bevægelsen.

For en ordens skyld skal indskydes, at Ernst Christiansen ikke var kommet til Flensborg fra det nordslesvigske bondeland. Han var nok født i Vejbæk i Bov sogn, men familien var flyttet til Flensborg, mens han var en lille dreng, kun 5 år gammel. Her voksede han op i Jørgensby-kvarteret, og han var et udpræget Flensborg-barn. (Jfr. Dorrit Andersen: Tyve år i en sønderjysk redaktion, Sdj. Årb. 1977).

Tønder Amts Avis blev ingen konkurrent for Flensborg Avis. Det nye blad klarede sig kun et fjerdingår, men fra anden side kunne Flensborg Avis nok føle sig trængt; alene det forhold, at bladet havde fået sit oplag delt ved grænsedragningen, således at hovedparten måtte sendes nord for grænsen, måtte skabe vanskeligheder.

Den konservative utilfredshed med Flensborg Avis blev ikke modsvaret af nogen anerkendelse fra Venstres side. Her kom modsætningen mellem $\mathrm{H}$. Jefsen Christensen og Kloppenborg-Skrumsager ind i billedet. Flensborg Avis havde klart støttet Kloppenborg. Et par dage efter det folketingsvalg, som ikke bragte Hans Jefsen Christensen det ventede mandat, skrev han til Ernst Christiansen: „Herude på vestkanten er der i mange kredse en voldsom harme mod Flensborg Avis på grund af dens vrangvillige holdning overfor min kandidatur, der vil have sin store part af skylden for, at Aabenraa-partiet sidder ene omkring fadet $i$ rigsdagen ... Kloppenborg-Skrumsager har intet rygstød i befolkningen og får det heller ikke, hvilket De med hans politiske løbebane burde være vidende om. Jeg kan betro Dem, at der fra forskellige sider er bestræbelser igang for at få mig ind som landstingsmand, og jeg har grund til at tro, at Aabenraa-folkene vil støtte det for ikke at få KloppenborgSkrumsager, såvel som til at tro, at det vil blive mødt med velvilje af venstrevælgerne nord for grænsen. Stemningen er meget delt mellem grev Schack og mig, men jeg ønsker absolut ikke Flensborg Avis' støtte, blot at De holder Dem ganske neutral, da en stærk agitation fra Flensborg Avis ikke i øjeblikket vil øve anden indflydelse end den at virke splittende (L. A. Åbenrå, Ernst Christiansens arkiv).

Jefsen Christensen havde ikke umiddelbart held med sig. Flensborg Avis støttede Kloppenborg-Skrumsager, og denne blev som nævnt valgt som landstingsmand af de valgmænd, der repræsenterede Flensborg-Venstre, men i sidste instans lykkedes det Jefsen Christensen ved hjælp af Venstres bestyrelse at blive tingvalgt medlem. Af alle sønderjyske rigsdagsmænd fra 
1920 var han nok den stærkeste personlighed, og han fik under regeringen Neergaard stor indflydelse på grænselandspolitikken.

Den 5. oktober 1920 åbnede rigsdagen; højtideligheden var præget af den glædelige udvidelse, som rigsdagen havde erfaret ved nu også at rumme sønderjyske medlemmer. De 5 repræsentanter for Aabenraa-Venstre sendte umiddelbart efter åbningen $\mathrm{i}$ fællesskab en hilsen til $\mathrm{H}$. P. Hanssen. De omtalte de festlige dage, men fortsatte: "Ja, det var fest, men midt $i$ det altsammen felte vi stærkere end nogensinde det unaturlige $i$, at du ikke var $i$ spidsen for os som vort folks kårne fører. I nationalpolitisk henseende har du været vor opdrager mere end nogen anden. Da det kneb, var du manden, der fylkede hæren. Du formåede selv at se ud over de nærmeste hindringer og give os udsyn over tidens nationale rørelser til styrkelse af vort håb. Du er manden, der har båret dagens byrde og hede, bảde som arbejder og fører!

Men nu blev det dine menige arvtagere, der blev bedt til fest, mens du sad hjemme. Ikke fordi du ikke kunne komme med, thi der er plads til dig, så snart du vil«, og de sluttede: "Vi håber, at den tid ikke må være fjern, da du igen er fremme i første linje. Din plads står åben, i den kan ingen af os gøre fyldest." (Grænsevagten 1920-21 s. 82).

De fem repræsentanter for Aabenraa-venstre betød en øget støtte for H.P. Hanssens synspunkter $i$ venstrepartiet som helhed, og den uklarhed, der havde hersket over regeringen Neergaards sønderjyske politik siden forsommeren 1920, blev hævet, da statsministeren i november 1920 markerede det standpunkt, at en grænseflytning, hvad enten det var mod nord eller mod syd, nu var indiskutabel. Dette klare standpunkt banede vejen for, at $H$. P. Hanssen senere kunne slutte sig til partiet Venstre. Men Det konservative folkeparti, der sikrede regeringen Neergaard et flertal, var endnu ikke at finde på denne linje.

Da den nyvalgte konservative folketingsmand Holger Andersen den 28. oktober 1920 tog ordet i folketinget, kritiserede han grænsedragningen. Han ville ikke medgive, at den nye grænse hvilede på selvbestemmelsesretten. Han fandt, at afstemningen den 14. marts 1920 hverken havde været fri, upåvirket eller hemmelig. Han tog afstand fra socialdemokraten C. N. Hauge, der under finanslovdebatten havde sagt, at den løsning, det slesvigske spørgsmål nu havde fået, var endelig og uigenkaldelig, og at den nye grænse derfor, som den eneste mulige, stod fast for alle tider. Holger Andersen sagde, at man også kan have den opfattelse, at dette ikke er tilfældet: „Det forekommer mig, at historien i så henseende taler er ret tydeligt sprog. Faste og urokkelige grænselinjer findes kun der, hvor de er dragne af naturens egen hånd. At en grænse, som ikke kan siges at fyldestgøre naturens krav, skulle være fast og urokkelig for stedse, kan man efter min mening kun sige, når man ikke kan 
eller vil se virkeligheden, som den er." Men Holger Andersen forklarede videre: "Men nu er denne grænse fastsat, og hvad man så end vil mene om den, er den en kendsgerning. Ingen tænker på, at der fra dansk side kan eller skal føres en politik med grænsens voldelige flytning for øje. Såfremt det slesvigske spørgsmål påny optages til forhandling, da kan dette kun ske gennem Folkenes Forbund.“

Holger Andersens formulering var ret moderat, men sandsynligvis har der i Det konservative folkeparti været visse brydninger angående dette spørgsmål, for da partiet 4.-5. november 1920 holdt landsrådsmøde blev der om den nationale politik vedtaget en passus, der gik noget videre. På forslag af redaktør A. Svensson havde samtlige de nye nordslesvigske delegerede for en stund forladt forsamlingssalen for i fællesskab at udarbejde det afsnit af resolutionen, der vedrørte de danske syd for grænsen. Afsnittet blev enstemmigt godkendt og lød:

"Mødet beklager dybt, at det trods alle bestræbelser ikke lykkedes at bjærge alle danske i Sønderjylland med hjem til Danmark. De mænd, der ved en udansk politik og fortsat modstand mod at indanke vort store nationale spørgsmål for vælgerfolkets domstol, har forskyldt, at tusinder af trofaste landsmænd måtte blive i udlændighed, har for stedse dømt sig selv.

Vi giver danskheden syd for den nye rigsgrænse vort håndslag og tilsiger vore udelukkede landsmænd al den støtte, vi politisk og nationalt, kulturelt og materielt er $\mathrm{i}$ stand til at yde dem. Den nu stedfundne løsning af det slesvigske spørgsmål svarer ikke til de forventninger, store dele af det danske folk med føje har næret om en fuldt retfærdig ordning af grænsespørgsmålet. Vi deler vore folkefællers håb om, at også deres kamp engang må få sin lykkelige løn." (Grænsevagten 1920-21 s. 127).

Den unge J. Christmas Moller fulgte synspunktet op, da han den 6 . november 1920 i folketinget sagde: „Det forekommer mig både umoralsk og tåbeligt at bringe ofre for at bevare danskheden i 2. zone, hvis slutmålet ikke er en grænseregulering."

Det fik J. P. Nielsen til at fremsætte nogle skarpe bemærkninger om, at "Flensborg-gruppen ikke kan ophøre med sine rumlerier $\mathrm{i}$ det nationale spørgsmål... Jeg må tilstå, jeg blev ganske forbavset, da man hævdede, at Flensborg skulle være en dansk by. Jeg har i 1894 arbejdet i Flensborg, og det, der mødte mig der, var ikke dansk ånd, dansk kultur og dansk sindelag. Nej, det var tysk ånd, tysk kultur og tysk sindelag. Man måtte ialtfald have en lygte, hvis man skulle ud at lede danskheden op dernede. Det er også betegnende, at den agitation, der anvendtes før afstemningen i Flensborg, overvejende blev ført på tysk ... «

Denne tale blev taget J. P. Nielsen meget ilde op. Order »rumlerier« blev 
angrebet mange gange i de Flensborg-venlige blade $\mathrm{i}$ den følgende tid, og $\mathrm{i}$ Flensborg Avis hed det 16. november 1920: „Med en vis undren har man set drøftelsen vedrørende vort fremtidsmål i den kongerigske presse. I radikale og socialdemokratiske blade og enkelte af Venstres aviser, på fremskudt plads i Hejmdal, har man rådet os til at slå os til ro med denne nye grænse som den endelige afgørelse. Andre blade har ikke villet udelukke alt håb, men opfrisket opfordringen: "Tal aldrig derom, men tænk altid derpå«. Atter andre deler tilfulde vort håb. Det konservative folkeparti har gjort det til sit." I det følgende argumenterede bladet efter den linje, at de danske syd for grænsen var lovlydige, men at Tyskland selv håbede på ændringer $i$ fredstraktaten. Skulle de danske så ikke have lov til det samme?

Det er på denne baggrund, og fordi pastor Schmidt på hjemmetyskernes vegne krævede grænsen flyttet nordpå, at statsminister Neergaard i folketinget den 10. november udtalte: "Denne regering vil respektere den nye grænse både til den ene og anden side. Vi kræver ikke blot respekt for grænsen af dem, der bor nord for den, vi vil selv vise samme respekt mod syd. Denne respekt vil vi vise, fordi vi skylder de magter, som overhovedet muliggjorde, at vi fik de sønderjyske landsdele indlemmet i Danmark, det hensyn at respektere den af dem på grundlag af Versaillestraktaten trufne afgørelse. Og vi skylder os selv det, thi uden en sådan respekt for grænsen kan den nationale opgave, vi har i de blandede egne, der er under dansk styre, ikke udføres på forsvarlig måde «, men han tilføjede: "Dette siger jeg, endskønt det jo ikke er nogen hemmelighed og ofte udtalt fra regeringens side, at vi havde ønsket grænsen draget anderledes, end den blev draget«. (Grsv. 1920-21 s. 126).

I efteråret 1920 var det altså stadig et politisk problem i Danmark, om grænsespørgsmålet skulle holdes åbent, eller om man skulle stå på standpunktet: Grænsen ligger fast, som regeringen nu gjorde. Denne meningsforskel fik betydning $\mathrm{i}$ forbindelse med de overvejelser, der var begyndt $\mathrm{i}$ sensommeren 1920, om en nyordning af de foreninger, der i kongeriget havde støttet de danske i Sønderjylland. Også i den genvundne del af Sønderjylland rejstes der samtidig organisationsproblemer, både hvad angik de "gamle« foreninger fra udlændighedstiden og de nye, der måtte komme til under de ændrede vilkår.

Ernst Christiansen havde foreslået, at alle gamle sønderjyske foreninger i kongeriget blev samlet $i$ en stor, landsdækkende "Grænseforening". I Nordslesvig måtte denne gren af organisationsarbejdet imidlertid begynde på bar bund. Peter Grau satte sig i spidsen i bestræbelser for at oprette en sønderjysk afdeling af Grænseforeningen, men der viste sig uenighed om, hvorvidt man i den nye organisation skulle søge at slå bro over grænsestridens kløft, eller om man især skulle appellere til Flensborg-tilhængerne og 
om man mere eller mindre direkte skulle holde grænsespørgsmålet åbent.

Peter Grau var på den moderate linje, og han kunne finde støtte derfor i et opråb udsendt af de nyvalgte sønderjyske rigsdagsmedlemmer, der søgte at kalde til samling på det nu givne grundlag. I et opråb til det danske folk hed det: "I det øjeblik, repræsentanter for de sønderjyske landsdele for første gang indtager deres sæde i den danske rigsdag, mindes vi med tak den støtte, det danske folk ydede os til bevarelse af vor danskhed under fremmedherredømmet.

Når vi nu begynder det uhindrede samliv med vort folk, som vi længtes efter og kæmpede for $i$ alle de mange år, går vore tanker af sig selv til de landsmænd, der lever uden for rigets grænser under vanskelige nationale kår.

Under den glæde, vi nu oplever med vort folk, føler vi derfor trang til at opfordre alle kredse af det danske folk til at samles $i$ et enigt arbejde for at støtte og hjælpe disse vore landsmænd $i$ deres bestræbelser for at bevare dansk sprog, sindelag og kultur.

Mange er de opgaver, der ligger og venter på deres løsning, ikke mindst på skolens og kirkens område. Vi opfordrer derfor vort folk til, hele landet over, at danne organisationer eller underbygge dem, der støttede os i kampen under fremmedherredømmet, $i$ det øjemed, med alle lovlige midler at støtte de danske i udlændighed til hævdelse af sprog og nationalitet." (Grænsevagten 1920-21 s. 82) Det var undertegnet af Holger Andersen (kons.), P. J. Refshauge, M. K. Gram, dr. Karberg, Chr. E. Christensen, A. Lebeck, H. D. Kloppenborg-Skrumsager (venstre), Chr. Lageri (rad.venstre), Jørgen Møller (soc.dem.) Man skal næppe se nogen demonstration i, at J. P. Nielsens navn ikke var med; han havde ikke haft bopæl i Sønderjylland før 1920.

Den 12. okt. 1920 holdtes i Tinglev et forberedende møde for at oprette en nordslesvigsk "Grænseforening «. Både Flensborg- og Aabenraa-folk deltog deri, og P. Grau var ivrig for at få alle kredse med. Der blev oprettet amtsudvalg med repræsentanter for begge retninger. Af mere fremtrædende Aabenraa-folk kan man nævne M. K. Gram og amtsskolekonsulent Nikolai Svendsen, Tønder.

Flensborg Avis var tilfreds med initiativet, der gik parallelt med de bestræbelser, der i kongeriget var igang for at samle de sønderjyske foreninger i en "Grænseforening«, men både i Nordslesvig og i det "gamle land « viste der sig modstand. En række foreninger ville bevare en mere fri stilling, og ved siden af Grænseforeningen dannedes et samarbejdsorgan med navnet "De sønderjydske foreningers fællesråd«. Denne sammenslutning stod lidt til højre for Grænseforeningen.

I fællesrådet samledes "Flensborg-samfundet“, landsforeningen "Højskamling«, Ligaen DDD (Danmark, Danebrog, Danevirke), Sønderjydsk 
Centralforening og Sønderjydsk Samfund. I Nordslesvig forholdt bladet "Danskeren" sig forbeholdent over for tanken om en stor samlende grænseforening, og bladet kunne ikke acceptere det opråb, de sønderjyske rigsdagsmænd havde udstedt, når 5 af disse parlamentarikere samtidig havde sendt en hyldest til H. P. Hanssen. "Man kan ikke på samme tid tjene H. P. Hanssen og den sydslesvigske danskhed. De to proklamationer med delvis de samme navne under viser bedst, hvor forvirrede og forvrøvlede forholdene efterhånden er blevet her i landet. « (18. oktober 1920). Man vil heraf forstå, at Danskeren havde mest sympati for fællesrådet, og bestræbelserne for at oprette en nordslesvigsk grænseforening fik i bladet følgende kommentar: "... I de nedsatte amtsudvalg findes navne både for Flensborg-venner og Flensborg-modstandere. Dette vil antagelig vanskeliggøre tilslutningen noget, idet der altid vil være folk, som ønsker at gøre et fremtidigt arbejde for Mellemslesvig i samme ånd og udfra samme synspunkter, som hidtil har været ledende for dem ... den ene krone kan være lige så god som den anden, kan man sige...For os, der ikke overser, at de pengebeløb, der er nødvendige til at skabe rammerne for arbejdet dernede, skal skaffes til veje, men samtidig fastholder, at det ikke er de danske kroner der, om det lykkes engang, skal bære landet hjem til Danmark, stiller sagen sig noget anderledes. Vi ønsker først og fremmest et sundt, dybtgående nationalt og kristeligt arbejde syd for den nye grænse, som ikke presser frugterne frem, men lader dem modnes til sin tid. Vi ønsker et roligt og dybt åndedrag $\mathrm{i}$, hvad vi foretager os, og en virkelig overbevisning om, at "det har slet ingen hast for den, som tror«. Dette program og denne overbevisning kan efter vort skøn kun deles af ligesindede med samme grundanskuelse og samme livssyn, og vi har grund til at vente, at der også i den nærmeste fremtid på denne basis vil søges dannet en sammenslutning hernede om at arbejde for og blandt folkefæller i Mellemslesvig.« (19. oktober 1920).

I Ribe Stiftstidende var tonen mere kras. Her skrev Argus 29. oktober 1920: "De usynlige magter, som nu forhindrer Danmark i at yde de danske i 2. zone hjælp ved at blande Flensborgmændene med de danske flensborgeres banemænd og ved at hæve sidstnævnte til skyerne, vil engang komme til at undgalde derfor".

De stridende gruppers erklæringer fik Mads Gram til at melde fra. Han skrev 28. oktober 1920 i Hejmdal: "For kort tid siden modtog jeg meddelelse om, at jeg var udpeget som medlem af arbejdsudvalget for Haderslev Vesteramt til dannelse af stedlige afdelinger af en "grænseforening“. Den nye sammenslutnings navn forekom mig mindre heldigt valgt, når der ønskes en samling om bestræbelser til støtte af vore landsmænd uden for Danmarks grænser så kort tid efter, at grænsestriden har sat sindene i bevægelse. 
Et navn kan imidlertid være mindre væsentligt, men det viser sig, at sammenslutningen har fremkaldt brydninger blandt de bestående sønderjyske foreninger. I disse brydninger ønsker jeg ikke at indblandes, men mener det rigtigst at afvente en afklaring, som må komme... " (Grænsevagten 1920-21 s. 89).

Det betød, at Grænseforeningen i Nordslesvig ikke blev en organisation, der slog bro over kløften, men fortrinsvis en forening af Flensborg-folk. I bladet Hejmdal fremsattes ønske om, at de, der arbejdede for en grænseforening, ville formulere et klart program. Det hed den 12. november 1920: "... Endnu har Grænseforeningen ikke tonet rent flag. Der foreligger udtalelser, hvorefter dens arbejde vil blive holdt inden for rammer, som også vi kan finde fuldt forsvarlige. Men der foreligger også, tilmed af flere af dens ledende mænd, udtalelser som peger $i$ en anden retning og tyder på, at den først og fremmest vil samle sig om løsningen af en stor politisk opgave: grænsens flytning sydpå. Med henblik derpå holder vi det for nødvendigt, at der tilvejebringes større klarhed, inden foreningen organiseres ud over Nordslesvig, da manges tilslutning sikkert vil være afhængig deraf. De foreninger, der vil arbejde syd for grænsen, må, finder vi, stille sig på det klare og uangribelige standpunkt, som regeringen står på. For så vidt det er tilfældet, vil vi også kunne yde dem vor kraftige understøttelse og være med til at fremme deres formål med varm energi. Vi håber, at stadig videre kredse må indse, at dette er det eneste forsvarlige standpunkt, og at hele det danske folk må kunne samles til enigt og frugtbart samarbejde på dette grundlag."

Dette tilbud om et samarbejde på det givne politiske grundlag blev skarpt afvist af Flensborg Avis, som mente, at kravet om, at Grænseforeningen burde tone rent flag, vistnok skulle tjene som en kæp i hjulet: "Det er ikke godt at vide, hvorledes bladet Hejmdal i øjeblikket "tænker sig den store "politiske« opgave at få grænsen flyttet sydpå «. Selvfølgelig bliver det de sønderjyske foreningers opgave at støtte dansk sprog og oplysning. Men ikke mindre vigtigt er den opgave at styrke selvhævdelsen i det danske folk. Der er her en kløft, som det ikke skal lykkes at skjule i en tåge af kønne ord ... Den tyske folketingsmand, tyske foreninger nord og syd for grænsen, officielle tyske repræsentanter har knæsat kravet om en ny grænseflytning. Skulle de danske syd for grænsen have mindre ret end de indvandrede tyskere i dansk land?

Der er yderligere sket den forandring, at der er oprettet et Folkenens Forbund, og der er udtrykkeligt af de ledende statsmænd henvist til, at fredstraktaternes bestemmelser ikke er uforanderlige... Med undren ser man i Hejmdal et forsøg på at give de danske syd for grænsen gode råd. De har gjort uheldige erfaringer med råd fra Aabenraa. Hvis de fra første færd 
havde vist dem den mest fjendtlige mistro, ville de have været bedre farne. Denne lære har de skrevet sig bag øret, og de skal nok selv vide, hvad de vil.“ (13. november 1920). Man forstår efter dette, at Aabenraa-folkene indtog en reserveret holdning overfor Grænseforeningen.

Hvad angik det formelle grundlag for Grænseforeningen, blev Hejmdals ønske imidlertid opfyldt. På Grænseforeningens stiftende møde den 2. november 1920 blev følgende uangribelige formålsparagraf vedtaget: "Foreningens hovedformål er ved alle lovlige midler såvel åndeligt som materielt at støtte og udvikle danskheden syd for grænsen." (Grænsevagten 1920-21 s. 154). Uanset de angreb, der blev rettet mod H. P. Hanssen og hans ligesindede af andre, udsendte $P$. Grau 13. november 1920 en af forsonlighed præget opfordring til at danne lokale afdelinger med en programerklæring for den påtænkte nordslesvigske organisation, som skulle neddæmpe modsætningerne. Men Danskeren var ikke tilfreds med denne opfordrings formulering: "... Det viser sig altså, som forudset, at alliancen med H. P. Hanssens mange meningsfæller $i$ grænsestriden også hurtigt vil føre til et arbejdsprogram, der i virkeligheden betyder en stiltiende anerkendelse af den H. P. Hanssenske løsning af grænsespørgsmålet. Der er ingen tvivl om, at Peter Graus programudtalelse også vil kunne gøre regning på H. P. Hanssens varmeste tilslutning. Det modsatte vil antagelig blive tilfældet på et nyt møde af de nordslesvigske konservative.« (14. november 1920).

Den konservative organisation i Nordslesvig havde indtil da været tilbageholdende. Inden for denne ramme virkede bảde P. Grau og A. Svensson. Det viste sig, at P. Grau ikke havde held til at få de delegerede ind på sin linje, medens Svenssons linje fik større støtte. Han havde som næunt sympati for Sønderjydske Foreningers Fællesråd, der blev oprettet den 28. okt. 1920. Den 3. nov. udsendte fællesrådet et opråb om tilslutning til en af de samarbejdende foreninger. Fællesrådets politiske formål var udtrykt $\mathrm{i}$ det ønske, der indeholdes i verslinjerne: "skænke os et Danmarkskort, hvor alt dansk igen er vort«. (Grænsevagten 1920-21 s. 136).

Flensborg Avis havde taget klart standpunkt for Grænseforeningen og mod Fællesrådet, men til forskel fra P. Grau ønskede avisen H. P. Hanssen og hans folk holdt udenfor Grænseforeningen. I et svar til Danskeren hed det: "Grænseforeningen vil utvivlsomt bane sig vej i Nordslesvig uden hensyn til angreb fra den ene eller den anden side. Mon Danskeren tror, at Peter Grau, Pøl og den konservative nordslesvigske folketingsmand (Holger Andersen) og Kloppenborg-Skrumsager med flere er gået over til H.P. Hanssens syn på grænsespørgsmålet? Tror den ikke det, så ses det ikke, hvad gavn dens angreb skal gøre. Fra de danske syd for grænsen skal det siges uden personlig brod, men i fuldt alvor, at det for os både er en sorg og en ydmygelse og føles som en 
ny bitter tilskikkelse, at nu ikke engang vore venner i Nordslesvig kan være fælles om vor nationale sag, men at der gøres ihærdige forsøg på at dele befolkningen efter partilinjer også i denne sag, hvor vi dag efter dag indtrængende har bedt om samling bag fronten. I kongeriget er der fremdeles to lejre. Skal spliden nu også bæres ned i Nordslesvig, hvor der dog kan bygges fra ny af, så er vi vel farne « (16. november 1920).

Med den holdning, som henholdsvis Flensborg Avis og Danskeren indtog, kan man godt forstå, at Grænseforeningen fik vanskeligheder, da lokalforeningerne i Nordslesvig skulle dannes. I Haderslev gik det nogenlunde, takket være Holger Andersen, der tog standpunkt til fordel for Grænseforeningen. I Tønder, hvor der holdtes et møde den 21. dec. 1920, var det lidt mere besværligt. Mads Varming fra Råhede var utilfreds med navnet Grænseforeningen, og han ønskede en klar udtalelse om, at foreningen ville respektere den nye grænse, mens andre var mere valne. Man drøftede også forholdet til den store Grænseforening og vedtog, at "Grænseforeningen i de sønderjydske landsdele bør oprettes som en selvstændig forening «. Det var helt på tværs af den linje, som Flensborg Avis ønskede fulgt. Forslaget fik følgende kommentar: "Det er ikke meget opmuntrende at læse om en sådan forening. På tysk side samles man $\mathrm{i}$ enighed og er fast bestemt på at yde tyskerne i Nordslesvig hvilken som helst støtte, de ønsker, med tydelig tilkendegivelse af, at man kræver grænsen flyttet igen. På dansk side mødes de udelukkede danskes atter og atter gentagne henstilling om en stærk og enig sammenslutning med de mærkeligste betænkeligheder. Kan man ikke forstå, at det for Nordslesvigs egen skyld er nødvendigt at samle dem, der ikke vil drive tyskerkurs og forberede en ny udlevering af sønderjysk jord.« (Grænsevagten 1920-21 s. 189 efter Flensborg Avis af 24. december 1920).

Endnu mere bitter var tonen i en nytårsartikel i Flensborg Avis den 3. januar 1920"... Lad de danske sammenslutninger nord for grænsen roligt afholde sig fra krigsråb og politiske krav, men det mangler bare, at de skulle begynde med at drive en ny Rubin-politik... Ikke af barmhjertighed, men for sin egen skyld må Nordslesvig støtte de udelukkede ved storslået samling af alle gode kræfter, ikke ved spredt og splittet foreningsarbejde."

Men ny splittelse var undervejs. Den 14. januar 1921 meddelte Danskeren, at der var oprettet en sammenslutning med navnet Foreningen Sydslesvig. Bag oprettelsen stod redaktør A. Svensson. Dens formål skulle være at styrke danskheden syd for grænsen "i ethvert arbejde, der er foreneligt med den tyske lovgivning “. For så vidt var der ikke stor forskel $i$ forhold til Grænseforeningens program. Men det hed videre, at foreningen ville "bidrage til en offentlig dansk mening, der ikke anerkender, at princippet om folkenes selvbestemmelsesret er bragt til en fuldstændig og retfærdig 
anvendelse på den del af Slesvig, der ligger syd for den nye grænse, men håber med de danske søndenskels, at deres sag engang må blive taget op til ny prøvelse, så langt dansk folkegrund når, og at der derigennem må kunne ventes en genforening af alle danske med moderlandet." Den nye forening søgte tilslutning til Sønderjydske Foreningers Fællesråd.

I offentligheden fik den en blandet modtagelse. Fyns Venstreblad udtrykte betænkelighed ved, at man ville hævde, at selvbestemmelsesrettens princip ikke var bragt til fuldgyldig og retmæssig anvendelse. Herpå svarede redaktør Svensson den 25. januar 1921: "Det kan naturligvis være temmelig ligegyldigt, hvorledes den radikale presse opfatter "Foreningen Sydslesvigu's tilblivelse og vedtægter eller ikke... Vi skal dog benytte lejligheden til at sige, at det ikke er de Sønderjydske Foreningers Fællesråd, der har konstitueret foreningen, men mænd fra Haderslev amt. Hvad lovene angår, så tilsigtes der tydeligt nok to slags virksomhed, en i Sydslesvig (landet fra Flensborg fjord til Danevirke) svarende til det uskyldige punkt 1 , og en i Danmark svarende til punkt 2. Dette sidste er for os hovedsagen. Thi det galder nu, som det gjaldt før krigen, at vække og vedligeholde genforeningshåbet for de danske syd for grænsen. $\mathrm{Og}$ da der er nok, der vil tie det ihjel, så vil Foreningen Sydslesvig tale om dette håb». (Grænsevagten 1920-21 s. 251).

Foreningen var næppe kommet i gang, før forudsætningerne fuldstændig ændredes. Grænseforeningen og Sønderjydske Foreningers Fællesråd sluttede sig den 3. februar 1921 sammen. De tilsluttede foreninger fik lidt mere spillerum, men formålsparagraffen blev ikke ændret. Kun to af de foreninger, der havde været med i Fællesrådet, holdt sig nu udenfor. Det var Ligaen DDD (den eksisterer idag som Slesvig-Ligaen) og Foreningen Sydslesvig. (Grænsevagten 1920-21 s. 201f).

Allerede den 20. januar 1921 var de to formænd, for Grænseforeningen professor F. Vinding Kruse og for Fællesrådet general Ulrich, blevet enige om at anbefale en sammenslutning. Redaktør Svensson var ikke tilfreds med, at formanden for Fællesrådet ikke havde indviet ham $i$, hvad der var $i$ gære. Foreningen Sydslesvig havde vel ikke nogen formel ret til at få meddelelsen om dette skridt, eftersom den ikke var indmeldt i Fællesrådet, men så meget større moralsk adkomst. Uoverensstemmelsen førte til en udførlig brevveksling mellem redaktør Svensson på Foreningen Sydslesvig's vegne og general Ulrich. (Danskeren 8. februar 1921).

I en artikelrække 7.-9. februar 1921 gennemgik redaktør Svensson hele problemet om »Arbejdet for den sydlige danskhed «. Han belyste striden mellem Grænseforeningen og Fællesrådet: „Samarbejdet med Aabenraamændene dyrkedes langt mere udstrakt hernede [i Nordslesvig], og hårdhændetheden overfor dem, der ikke kunne være med i dette arbejde, var ikke 
mindre, snarere større. Således krævede P. Grau ved det konservative delegeretmøde i Tinglev i sin tid på det bestemteste, at her i Nordslesvig måtte der kun være plads for Grænseforeningen og ikke for Fællesrådet. Det lykkedes ikke at få vedtaget en resolution i den retning. Til gengæld forsømte Flensborg Avis ingen lejlighed til at fremhæve, at Grænseforeningen var det eneste rigtige ... Så dannedes Foreningen Sydslesvig. Man skulle tro, at den sydlige danskhed ikke havde råd til at afvise en sådan håndsrækning nordfra. Ikke desto mindre udtrykte Flensborg Avis temmelig tydeligt sin forventning om, at foreningen ikke måtte blive til noget, og dokumenterede således påny, som så mange gange før, hvor vanskeligt bladet har ved at bedømme nordslesvigske forhold, når det drejer sig om danskhedens ve og vel syd for grænsen.“

I den følgende artikel udtalte Svensson sin forbavselse over, at Aabenraamanden, amtsskolekonsulent Nicolai Svendsen, var blevet medlem af Grænseforeningens hovedstyrelse, og at redaktør, folketingsmand Anders Lebeck, der var kasserer i den Nordslesvigske Skoleforening, var blevet hilst velkommen af de danske syd for grænsen med henblik på deres skolearbejde, og han mente samtidig, at problemet H. P. Hanssen meldte sig i horisonten, og der henvistes i artiklen til en udtalelse i Hejmdal om, at H. P. Hanssen i det øjeblik, han måtte ønske at indtræde $\mathrm{i}$ aktiv politik, ville blive båret af en bred folkebølge ind i rigsdagen. Redaktør Svensson mente, at denne forventning ville holde stik, og fandt, at $H$. P. Hanssen under sin påtvungne tilværelse som privatmand havde gjort et vellykket forsøg på at genrejse og konsolidere sin noget rystede magtstilling i Nordslesvig. Videre hed det: „Flensborg Avis har efter vort skøn lettet ham dette arbejde. I stedet for roligt og målbevidst at fastholde skillelinjen mellem dem, der stod de danske bi i grænsestriden, og dem, der svigtede, har bladet snart talt et sprog, der styrkede Hanssens position i stedet for at svakke den, og snart forholdt sig så anerkendende overfor de tidligere bitre modstandere, at linjerne udviskedes. Også den ubegribeligt ensidige måde, hvorpå Flensborg Avis har påtvunget befolkningen den blakkede nordslesvigske grænseforening, vil vise sig at være et skridt i den retning. Man må endelig ikke tro, den dag H. P. Hanssens politik igen bliver en magtfaktor $\mathrm{i}$ Nordslesvig, at den nordslesvigske grænseforening da kan dæmme op imod »flodbølgen«. Den vil på spørgs målet H.P. Hanssen splittes som avner for vinden. Kun en organisation af fast og ensartet støbning, således som Foreningen Sydslesvig var tænkt at være, kan da optage kampen. Heller ikke den store danske Grænseforening vil vise sig at være tilstrækkelig. Thi det er i Nordslesvig, at kampen skal føres. I Nordslesvig har Hanssens politik sin styrke, kun der kan den i længden modvirkes... Flensborg Avis har modvirket os og banlyst Foreningen 
Sydslesvig, så vidt det var bladet muligt. Fællesrådet, som vi skulle slutte os til, er ophørt at eksistere. Foreningen Sydslesvig har overvejet at ophøre, men vil fortsætte under visse forudsætninger.«

Ret længe kunne Foreningen Sydslesvig under de givne forudsætninger dog ikke fortsætte. Den 22. august 1921 blev foreningen opløst; bestyrelsen opfordrede medlemmerne til at slutte sig til Ligaen DDD. Den havde da ca. 700 medlemmer og rådede over en kassebeholdning på kr. 1.860. Det blev besluttet at hensætte 10.000 mark til kirkeligt arbejde i landdistrikterne og 10.000 mark til brug for enten en dansk landbrugs- eller husholdningsskole, hvis en sådan måtte blive oprettet. (Grænsevagten 1921-22 s. 45f).

Grænseforeningen for Nordslesvig blev definitivt oprettet 18. marts 1921 og nåede relativt hurtigt en stor tilslutning. Blandt bestyrelsesmedlemmerne kunne man notere også en del tilhængere af Aabenraa-retningen, omend Flensborg-tilhængerne havde overvægten, og Grænseforeningen blevikke en samlende organisation for de to retninger, men i det gamle land blev Grænseforeningen den altdominerende sønderjyske forening.

I Nordslesvig var billedet mere broget. Her virkede på forhånd flere landsdelsdækkende nationale organisationer, som nu måtte tilpasse sig de nye forhold; det gjaldt dog ikke Vælgerforeningen, som havde mistet sin eksistensberettigelse. I november 1920 blev det vedtaget at opløse den; selve opløsningen fandt sted i oktober 1921. Dens midler gik til det såkaldte "jernfond«, der blev stillet til rådighed for det kulturelle arbejde syd for grænsen. Jernfondet eksisterer stadigvæk, men inflationen har været hård ved dets midler.

I modsætning til Vælgerforeningen havde Skoleforeningen og Sprogforeningen stadig store opgaver at varetage. Skoleforeningen havde - som før krigen - også i overgangstiden ydet støtte både til unge fra Nordslesvig og Mellemslesvig til højskoleophold i Danmark, og den fortsatte denne del af sin virksomhed uændret. Den fik også kontakt til den i maj 1920 nyoprettede Dansk Skoleforening Flensborg. Denne kontakt gik udenom den i juni 1920 dannede Slesvigske forening. Det havde varet redaktør Ernst Christiansens opfattelse, at denne nye forening skulle være altomfattende. Han skrev: "Den slesvigske forening, som skal være vælgerforening, sprogforening og sammen med den flensborgske skoleforening også skoleforening, samler til sine udvidede bestyrelsesmøder repræsentanter for alle danske hernede." (Grænsevagten 1920-21 s. 93). Hvad skolearbejdet angik blev dette program ikke opfyldt. Formanden for Den nordslesvigske skoleforening, Hans Jefsen Christensen, søgte kun forbindelse med Dansk Skoleforening, og den nordslesvigske organisation blev et værdifuldt rygstød for den sydslesvigske. Hovedparten af midlerne til skolerne i Flensborg og omegn kom fra den 
danske stat, men der var "personalunion" mellem Skoleforeningen og det udvalg, der administrerede statens støtte. H. Jefsen Christensen var toneangivende begge steder.

Den 22. december 1920 holdt Den nordslesvigske skoleforening et møde for at drøfte foreningens fremtidige organisationsform, med det formål at koncentrere arbejdet $i$ de vanskelige egne nord for grænsen $i$, "den skæve firkant« som man sagde, og ligeledes syd for grænsen. I Skoleforeningen kunne Aabenraa- og Flensborg-folk nok arbejde sammen, selvom foreningens kasserer gennem mange år, folketingsmand Anders Lebeck, politisk var en anstødssten for Flensborg-folkene.

Om Lebecks valg til folketinget havde Flensborg Avis den 4. okt. 1920 skrevet: »Det er nogle som mener, at nu efter at afgørelsen er faldet, skal vi så hurtigt som muligt glemme og tilgive og søge forbund med dem, der har villet udelukke os. Det falder ikke nogen hernede ind at leve på nag og bitterhed. Men det ville hævne sig på os selv, hvis vi ville bygge noget på støtte fra en lejr, dèr indleder sin rigsdagsvirksomhed med signaler som hr. Lebecks."

Nu havde Lebeck som Skoleforeningens kasserer gennem mange år taget imod ansøgninger til støtte af højskole- og efterskoleophold også fra sydslesvigere, og også mens grænsekampen rasede hårdest. Da en omdannelse af Skoleforeningen kom på tale, skrev han: "Skoleforeningen har under sin 30-årige virksomhed på sit område gjort et betydeligt arbejde for den danske ungdom syd for den gamle grænse. Bestyrelsen har altid med særlig imødekommenhed ydet hjælp til unge fra de vanskelige egne til at komme på danske skoler. I dette forhold er der heller ikke ændret noget ved fastsættelsen af den nye grænse. Samtlige ansøgninger, som i de senere år og indtil dato er indgået fra Flensborg og Mellemslesvig, er bleven bevilgede. Når foreningen nu, under ændrede former som de nye forhold kræver, fortsætter sit arbejde $\mathrm{i}$ Flensborg og Mellemslesvig, er den i bedste overensstemmelse med sine traditioner." (Grænsevagten 1920-21 s. 185).

Efter genforeningen fandt Hans Jefsen Christensen det hensigtsmæssigt, at Skoleforeningen skulle kunne hverve medlemmer ud over hele Danmark. I Flensborg Avis fandt han ingen forståelse for sådanne planer. Den 2. januar 1921 skrev avisen: "Medens adskilligt taler for, at Skoleforeningen fortsætter i Nordslesvig for at afvente, om der er trang til den også i fremtiden, erfarer man med nogen forundring, at den vil søge udvidelse i kongeriget. Knap er man nået til de to store sønderjyske sammenslutninger (Grænseforeningen og Fællesrådet), før den tredie søger at skaffe sig indpas. Skoleforeningen vil nord for Kongeåen ikke betyde en styrkelse, men en svækkelse, med mindre den tager udelukkende sigte på en høst i radikale kredse, der i grænsespørgsmålet har samarbejdet med vore tyske modstandere." 
Den sidste sætning var en grov beskyldning, og Jefsen Christensen gav svar på tiltale 4. januar: ... »Det er mig ganske uforståeligt, at Flensborg Avis mener at turde tage ansvaret for at tilbagevise nogen dansk, ligegyldigt hvor han eller hun end har stået i grænsespørgsmålet, der kommer og melder sig som deltager nu i et opbyggende arbejde af åndelig og kulturel natur syd for den grænse, som nu er sat, og som vi, med eller mod vor vilje, må regne med, indtil udviklingen på den ene eller anden måde fører os frem til andre muligheder ... Da Skoleforeningen i sin tid stiftedes herude på vesteregnen, var der mange kloge folk $\mathrm{i}$ vor landsdel, der mente, at en sådan forening var dog ganske overflødig. Vi havde allerede to store nationale foreninger: Sprogforeningen og Vælgerforeningen. Fik vi nu den tredje, ville det bare skade tilgangen til de allerede stiftede foreninger og skabe forvirring $i$ rækkerne.« (Fl.Av. 4. jan. 1921) Skjult i den sidste bemærkning lå en kritik af redaktør Jens Jessen, Flensborg Avis, der havde været en skarp modstander af, at der oprettedes en Skoleforening. Men kendsgerningerne havde vist, fortsatte Jefsen Christensen, at der også var plads og opgaver for Skoleforeningen.

Hertil svarede Flensborg Avis straks den 5. januar 1921: "Landstingsmand H. J. Christensen har næppe fulgt så dårligt med $\mathrm{i}$ den hidtilværende drøftelse, så han ikke ved, hvorfor Flensborg Avis og mange venner af den sønderjydske sag har opfordret til samling. Selvfølgelig er det ikke for at formindske støtten til de udelukkede, men for at forøge den. Een stor forening i hver by betyder mere end fem små; een stor i hele landet, der er stor nok til at påvirke den offentlige mening, mere end en snes mindre, der fører en private tilværelse ... Det er for tidligt hos os at påkalde venlige følelser for dem, der har arbejdet på at udelukke os. Det er vel ikke os, der har pligter mod dem, men dem, der skylder deres fædreland oprejsning."

Ved generalforsamlingen den 5. jan. 1921 blev foreningens navn ændret til »Sønderjysk skoleforening«. I jubilæumsbogen "Sønderjysk Skoleforening 1892-1942 « har Hans Jefsen Christensen nærmere gjort rede for de brydninger, der her kort er omtalt.

Trods udvidelsen til at omfatte hele Danmark vedblev skoleforeningen dog at have sit tyngdepunkt i Nordslesvig, men der bestod som nævnt et samarbejde mellem de to skoleforeninger nord og syd for grænsen. Til Sydslesvig gik statsmidlerne gennem et af Statsministeriet den 21. marts 1921 nedsat "Udvalg til fordeling af bevillingerne til støtte for dansk sprog og kultur i udlandet “. Dette udvalg havde gennem 1920'erne mellem $200.000 \mathrm{kr}$. og $300.000 \mathrm{kr}$. til rådighed om året, men heraf gik også beløb til danske lektorer ved udenlandske universiteter og til Dansk kirke i udlandet. De fleste 
midler gik dog til dansk privatskolevirksomhed i den tidligere 2. zone. I 1922 blev udvalget henlagt under undervisningsministeriet.

Foruden formanden, Hans Jefsen Christensen, var de øvrige medlemmer i første omgang folketingsmand Holger Andersen og amtsskolekonsulent Nicolai Svendsen. Senere blev alle partier repræsenteret, men man går næppe nogen for nær, når man hævder, at Jefsen Christensen var den centrale skikkelse, sålænge udvalget bestod.

Af de store nationale organisationer skal endnu nævnes Sprogforeningen. Også den blev reorganiseret i 1921. En af dens hovedopgaver før 1914 var arbejdet med de mange bogsamlinger, spredt ud over landsdelen. Efter 1920 trådte den danske bibliotekslovgivning i kraft, og der blev oprettet sognebiblioteker i så godt som alle sogne. Gennem Sprogforeningens sekretær, Jakob Petersen, der samtidig blev bibliotekar ved centralbiblioteket $\mathbf{i}$ Aabenraa, var Sprogforeningen med i oprettelsen af sognebiblioteker. Mange mente nu, at Sprogforeningen var overflødig, men der var stadig opgaver. H. P. Hanssen blev valgt til formand (også for Landsbiblioteket i Aabenraa); i tiden efter genforeningen blev Sprogforeningen basis for hans virke, og han vedblev som formand til sin død i 1936.

Som tingene havde udviklet sig, blev Sprogforeningen præget af Aabenraaretningens folk. Ved reorganisation blev så fremtrædende Aabenraa-folk som J. H. Schmidt, Vojensgaard, Jørgen From, Fjelstrup, M. Refslund Poulsen, Bovlund, og fru M. Andresen, Aabenraa, enke efter den tidligere formand, M. Andresen, indvalgt i tilsynsrådet. Flensborg-retningen var repræsenteret af den meget forsonlige P. Gad, Hejsel, mens redaktør Jessens enke, Marie Jessen, trådte ud i 1920.

Der var talrige opgaver at tage fat på i Nordslesvig. H. P. Hanssen var bl.a. meget ivrig for at få oprettet forsamlingshuse, især i den "skæve firkant «, han formidlede talrige fadderskabsforbindelser til denne egn. Der blev ydet støtte til foredragsvirksomhed og ungdomsarbejde. Den blå sangbog og almanakken var fortsat vigtige opgaver. Syd for grænsen blev det traditionelle arbejde videreført ved støtte til det nyindrettede bibliotek på Flensborghus og ved uddeling af sangbøger, hæfter og illustrerede blade.

De modsætninger, der havde præget grænsestriden, fortsatte i mange år i form af personlige sym- og antipatier, men meget hurtigt efter 1920 viste det sig, at det tyske pres blev så hårdt, både nord og syd for grænsen, at man nødvendigvis måtte rykke sammen på dansk side for at forsvare det, der var opnået i 1920. Grænseforeningen, Skoleforeningen og Sprogforeningen indgik således i midten af 1920'erne i et koordinerende samarbejdsudvalg, men det organisatoriske grundlag fra 1920-21 blevikke ændret, det viste sig at være særdeles holdbart, og det eksisterer i store træk den dag idag. Striden 
mellem Flensborg- og Aabenraa-folkene ebbede efterhånden ud, men i Løgumklosterkredsen vedblev i mange år, Flensborg-venstre med at have en særlig fraktion i venstres organisation. 
